College of William \& Mary Law School William \& Mary Law School Scholarship Repository

1976

\title{
The Legal Implementation of Coastal Zone Management: The North Carolina Model
}

Thomas J. Schoenbaum

Ronald H. Rosenberg

William \& Mary Law School, rhrose@wm.edu

\section{Repository Citation}

Schoenbaum, Thomas J. and Rosenberg, Ronald H., "The Legal Implementation of Coastal Zone Management: The North Carolina Model" (1976). Faculty Publications. 671.

https://scholarship.law.wm.edu/facpubs/671

Copyright c 1976 by the authors. This article is brought to you by the William \& Mary Law School Scholarship Repository. https://scholarship.law.wm.edu/facpubs 


\title{
政uke $\mathfrak{X}$ aw $\mathfrak{J}$ oumal
}

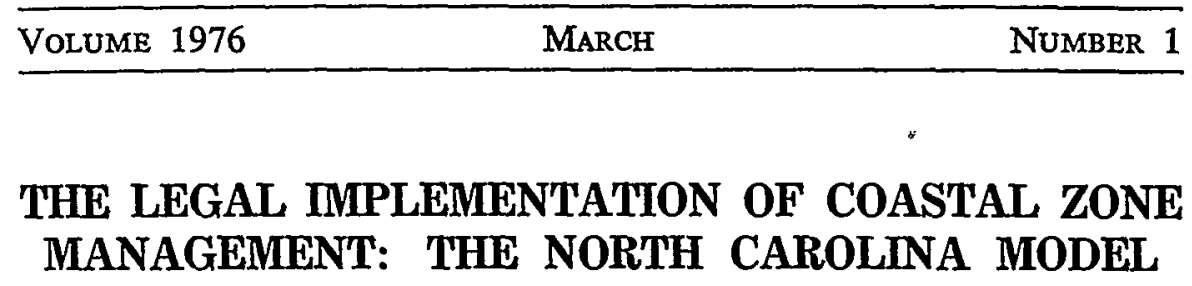

\author{
THOMAS J. SCHOENBAUM* \\ RONALD H. ROSENBERG**
}

OUTLINE

INTRODUCTION

I. The Statutory Framework: The North Carolina Coastal area ManageMENT ACT

A. Planning

B. Implementation: The Legal Effect of Planning

II. A Management System to Implement Planning

A. The Function of Traditional Forms of Land Use Controls: Zoning, Subdivision Regulation, and Capital Improvement Budgeting

B. Environmental Impact Analysis As a Supplement to the Zoning Process

C. State and Federal Regulatory and Program Activities: Permit Coordination and Plan Revision

III. Taxation Policy and Coastal Zone Management
A. Impact on Landowners
B. Preferential Property Tax Assessment

IV. Government Acquisition and OWnership Policies and Coastal Zone ManageMENT

A. Coordinated Use of the Acquisition and Ownership Powers to Implement Coastal Zone Management

B. Additional Possible Uses of the Acquisition Power

1. Transferable Development Rights

2. Land Banking

3. Natural Preservation Through a Land Conservancy Trust

Conclusion

* Professor of Law, University of North Carolina. A.B. 1961, St. Joseph's; J.D. 1965, University of Michigan.

** Attorney-Advisor, Office of Legislation, Environmental Protection Agency, Washington, D.C. The viewpoints expressed in this Article are the personal opinions of the authors alone and should not be construed as the policy of the Environmental Protection Agency. The preparation of this Article has been partially supported by the National Oceanic and Atmospheric Administration Sea Grant Program under Grant No. GH 103. 


\section{INTRODUCTION}

Most of the coastal states of the nation are in the process of creating coastal zone inanagement programs in response to the Coastal Zone Management Act of 1972 (CZMA), ${ }^{1}$ which inakes federal funds available for the development and administration of such programs. The first stage of this effort, program development, requires each state receiving federal funds to (1) identify the boundaries of the coastal zone planning area, (2) define the permissible land and water uses that have a direct and significant impact on coastal waters, (3) designate environmentally critical areas, (4) enumerate the means by which proposed control over land and water uses will be exercised, (5) designate broad priority uses in particular areas, and (6) describe the appropriate organizational structure to miplement the program. ${ }^{2}$

The details of the management programs are left to the states, but it is apparent that the CZMA essentially requires coastal land use planning centered around a land classification system, and the designation and protection of critical environmental areas. The states that are developing such systems, however, are beginning to realize that no matter how carefully the planning process is carried out, the new coastal management laws will founder if the legal mechamisms for implementation are inadequate and are not made an integral part of the planning process.

Yet developing an effective land use guidance system for coastal areas is difficult. The federal guidelines under the CZMA give the states a choice of several possible methods: state standards for local implementation subject to state review and approval, direct state regulation and implementation, state administrative review of all land and water use decisions, or a combination of these techniques. ${ }^{3}$ This is not much help since total control by the state is seldom politically feasible, and zoning, which is the only local meclianism specifically nientioned in the federal guidelines, ${ }^{4}$ is subject to well-known deficiencies. ${ }^{5}$ Municipal growth control mechanisms, now a major topic of discussion, ${ }^{6}$ would

1. 16 U.S.C. $\$ \$ 1451-64$ (Supp. III, 1973).

2. Id. $\S \S 1455$ (c)(1)-(6); 15 C.F.R. $\S \S 920.11-.16$ (1975).

3. 16 U.S.C. $\$ \S 1455$ (e)(1)(A)-(C) (Supp. III, 1973); 15 C.F.R. $\$ 920.14$ (1975). See generally Koppelman, Models for Implementing the CZMA's Concept of State-Local Relations, 16 WM. \& MARY L. REv. 731 (1975).

4. 15 C.F.R. $\$ 920.14$ (a) (1) (1975).

5. For a review of the inherent problems of zoning as a land use control mechanism, see Council on Environmental Quality, FifTh ANnual Report $51-53$ (1974). See also text accompanying notes 61-64 infra.

6. The literature is voluminous. For a good, general bibliography, see Freilich \& Gleeson, Municipal Growth Guidance Systems, A Preliminary Working Bibliography, in 
seem to have value in coastal zone management insofar as they present methods for controlling the timing, sequence, and location of development. Growth control, however, is not the only issue in coastal zone management. Regional and national concerns must be addressed. The CZMA requires each state to hist land and water uses that have benefits which extend beyond the boundaries of particular municipalities, mcluding "national imterest" uses and facilities. ${ }^{7}$ The state program must provide "a method of assuring that local land and water use regulations do not unreasonably restrict or exclude" such uses. ${ }^{8}$ States must therefore determine what constitutes an unreasonable exclusion of regional or national uses.

The implementation of coastal zone management programs requires the elaboration of a land use guidance system that is open to orgamic growth and responsive to economic opportunity, but one that affords maximum protection to critical environmental areas and the natural processes of the coastal area. The point of departure for such a system should be the natural carrying capacity of the resources of the area as determined by objective study of its soils, water, air, and natural systems, as well as its institutional resources. ${ }^{\circ}$

The concept of carrying capacity was first used as a resource management tool in park and rangeland management ${ }^{10}$ to determine the threshold of use intensity beyond which the destruction of the support systems of the area would occur. Its application to regional planning is, however, quite new: the idea is to determine the possible uses of an area of land by analyzing its natural characteristics. This implies that objective limits for the use of land exist, and that there are inherent limits beyond which degradation and irreversible damage will result. ${ }^{11}$ The

3 Management and Control of Growth 552 (R. Scott ed. 1975). Ordinances designed to limit or slow growth have been adopted in Boca Raton and Dade County, Florida; Ramapo, New York; Fairfax County and Loudoun County, Virgimia; Montgomery County and Prince George's County, Maryland; Boulder, Colorado; Petaluma and Sacramento County, California; and Salem, Oregon. These generally are rapidly urbanizing areas around large cities. For case studies of these jurisdictions, see Einsweiler, Gleeson, Ball, et al., Comparative Descriptions of Selected Municipal Growth Guidance Systems, A Preliminary Report, in 2 MANAgEMENT AND CoNTROL OF GROWTH 283 (R. Scott ed. 1975).

7. 16 U.S.C. $\$ 1455$ (c) (8) (Supp. III, 1973).

8. Id. $\$ 1455(\mathrm{e})(2)$. See generally Brewer, The Concept of State and Local Relations Under the CZMA, 16 WM. \& MARY L. REv. 717 (1975).

9. See generally D. Godschalk, F. Parker \& T. KNoche, Carrying Capacity: A Basis for CoAstal Planning? 130-44 (1974). Carrying capacity is one of the fundamental concepts of the North Carolina Coastal Area Management Act. See N.C. GEN. STAT. \$ 113A-102(a) (1975).

10. D. GodschalK, F. PARKER \& T. KNOCHE, supra note 9, at 4-7.

11. Id. at 131-32. 
most sophisticated refinement of this technique has been suggested by Professor Howard T. Odum, who has developed an energy-based computer modeling technique with diagrammatic representation of all the components of a given natural support system as its point of departure. Hypothetical changes in the system can then be tested to determine their effect on the carrying capacity of the natural support system. ${ }^{12}$

Although valid as a threshold consideration, this version of the concept of carrying capacity is not a suitable regulatory technique. It ignores the reality that the carrying capacity of any given area is dynamic: the carrying capacity can almost always be changed or expanded by institutional investment and the importation of energy-imputs from the outside..$^{13}$ In addition, it is erroneous to assune that carrying capacity is an objective guide to decision-making. Since its limits can be expanded by the importation of resources from other areas, and since environmental standards presume some allowable degradation, carrying capacity must be regarded as a political decision resting on value judgments. The application of a land use guidance system based on a dynamic concept of carrying capacity must thus await legislative and adimimistrative definition of the resource baselines, i.e. the minimun standards for various resources.

In most coastal states, the basehines for certain resources have been legislatively defined. Air and water quality standards are being defined pursuant to federal legislation. ${ }^{14}$ Dredge and fill and dune protection laws are designed to protect the contours of coastal areas and particular types of plant communities. ${ }^{15}$ A baseline for water withdrawals and use

12. See generally INTERFACE FOUR: URBAN DESIGN STUDIO, REPORT FOUR 13-24 (Dep't of Architecture, University of Florida, J. Shadix ed. 1974); H. Odum, ENVIRONMENT, POWER AND SOCIETY (1971).

13. D. GODSCHALK, F. PARKER \& T. KNOCHE, supra note 9, at 132.

14. Ambient air and emission limitations and standards are being developed and enforced pursuant to the Clean Air Act Amendments of 1970, 42 U.S.C. $\$ \S 1857$ et seq. (1970). Effluent standards and receiving water standards for estuaries and surface water are an important feature of the Federal Water Pollution Control Act Amendments of 1972, 33 U.S.C. \$\$ 1251 et seq. (Supp. III, 1973).

15. In North Carolina, for example, no person may damage or remove sand dunes or conduct dredging or filling in any salt marsh vegetation area without a permit. N.C. GEN. STAT. \& 104B-4 (1972); id. \&\$113-229 to -230 (1975). Similar legislation is in effect in other states. E.g., ME. Rev. StaT. ANN. tit. 38, \& 471 (Supp. 1975); N.H. Rev. Stat. ANn. $\S 483-A: 1$ (Supp. 1973). See generally Ausness, A Survey of State Regulation of Dredge and Fill Operations in Nonnavigable Waters, 8 LAND \& WATER L. Rev. 65 (1973). Under a newly established program under section 404 of the 1972 Federal Water Pollution Control Act Amendments, the United States Army Corps of Engineers and the Environmental Protection Agency also manage the contour and shape of coastal water bodies and the integrity of the land-water margin. 33 U.S.C. $\$ 1344$ (Supp. III, 1973); 40 Fed. Reg. 31,319 (1975); id. at 41,291. 
has often been established. ${ }^{16}$

Still, baselines for particular resources are not enough; carrying capacity becomes a practical tool only after baselines for the functioning of natural systems have been legislatively and administratively determined. This void can be filled by planning and by designating critical environmental areas, prerequisites to funding under the CZMA, ${ }^{17}$ which becounes clear when one considers that the purpose of the designation of critical areas is not merely to protect a geographic unit but is primarily to preserve the ongoing natural systems. ${ }^{18} \mathrm{~A}$ political decision has been made to protect natural systems from degradation whether resulting from their direct use or from activities outside such areas which may have an indirect adverse impact on their functioning.

The thesis of this Article is that the dynamic concept of environmental carrying capacity should be used, in addition to more traditional planning tools, in the implemnentation of a state coastal zone management program. This can be accoinplislied only through a coherent system that both incorporates traditional regulatory techniques, such as zoning and subdivision control, and creates supplementary legal tools for better implementation of the carrying capacity concept. The system must also provide for possible major revisions in the carrying capacity baselines through the political process. In connection with such a change-which would usually be a decision to allow greater degradation-it is important that legal mechanisms be provided to allow the greatest possible public scrutiny and debate before a decision is reached.

In order to construct such a model, it is useful to focus on a particular jurisdiction. The problems in North Carolima, which is more advanced in the development of a coastal zone management progran than most states, ${ }^{19}$ have been cliosen as typical of those inherent in the

16. North Carolina has established a procedure for subjecting water utilization in excess of 100,000 gallons per day to a permit procedure; the mechanism is triggered by a declaration of a "capacity use area" by the Environmental Management Commission. N.C. GEN. STAT. \$143-215.15 (Supp. 1975). Other states, such as Florida, comprehensively regulate the use of water resources. See, e.g., Water Resources Act of 1972, FLA. STAT. ANN. \$ $\$ 373.013$ et seq. (1974).

17. 16 U.S.C. $\$ \S 1455$ (c) (1), (9) (Supp. III, 1973).

18. Id. $\$ 1452(\mathrm{a})$.

19. Comprehensive coastal zone management laws have been enacted in several coastal states. E.g., CAL. PuB. RES. CODE $\S \S 27000-650$ (West Supp. 1975); HAWaII REv. STAT. \$\$ 205A-1 to -3 (Supp. 1974); N.C. GeN. Stat. §§ 113 A-100 to -128 (1975); R.I. GEN. LAWS ANN. \$\$ 46-23-1 to -16 (Supp. 1974); Wash. Rev. Code ANN. \$\$ 90.58 .010 to -.930 (Supp. 1974). Some coastal states, such as Oregon and Florida, have adopted statewide comprehensive planning laws that also apply in the coastal zone. FLA. StaT. ANN. \$\$ 380.012-.10 (1974); ORE. Rev. StaT. $\$ \$ 215.505-.990$ (1973). Most 
[Vol. 1976:1

implementation of such a program. North Carolina is one of the very few states to undertake the coordinated development of land use plans simultaneously by a great number of counties and municipalities in a large geographic area, an alternative to the geographically limited growth control models. North Carolina's coastal zone manageinent program is also a prototype which seeks to employ a combination of the three methods specified in the CZMA for controlling land and water uses: direct regulation by the state, local regulation in accordance with state-established standards, and local regulation subject to state review.

\section{The Statutory Framework: \\ The North Carolina Coastal Area Management Act}

After almost a decade of preparation, North Carohina acquired the legislative authority to develop a coastal zone management program in 1974. ${ }^{20}$ The North Carolina Coastal Area Management Act (CAMA) ${ }^{21}$ embodies many of the features of the Model Land Development Code of the American Law Institute. ${ }^{22}$ A new state agency, the Coastal Resources Commission, was created and given the principal responsibility for the development of the coastal zone management program. ${ }^{23}$ Local governments are also given important functions under the CAMA; unlike some state land use laws, ${ }^{24}$ the CAMA gives regional orgamizations only a very minor role.

\section{A. Planning}

The process of formulating a land use plan for the twenty-county

coastal states are in the process of trying to develop coastal zone management programs. See generally E. Bradley \& J. Armstrong, A Description and ANalysis of Coastal Zone and Shoreland Management Programs in the United States (1972).

20. For the legislative history and an analysis of the North Carolina legislation, see Glenn, The Coastal Area Management Act in the Courts: A Preliminary Analysis, 53 N.C.L. REv. 303 (1974); Heath, A Legislative History of the Coastal Area Management Act, 53 N.C.L. REv. 345 (1974); Schoenbaum, The Management of Land and Water Use in the Coastal Zone: A New Law is Enacted in North Carolina, 53 N.C.L. REv. 275 (1974).

21. N.C. GEN. STAT. $\S 113 A-100$ to -128 (1975).

22. ABA-ALI, A Model Land Development Code (Proposed Official Draft, 1975).

23. N.C. Gen. Stat. § 113A-104 (1975).

24. California, for example, relies on regional agencies to oversee the implementation of the coastal zone management program. CAL. PUB. RES. CodE $\$ 27400$ (West Supp. 1975). In North Carolina, as in most states, regional planning organizations are essentially powerless arms of local governments. See Paul, Regional Governments' Interests, in Proceedings of a Conference on Coastal Management 50, $51-52$ (UNC Sea Grant Publication UNC-SG-74-16, 1974). In formulating the CAMA, the legislature decided to establish a state-local management program and not to upgrade the powers of regional organizations. See Heath, supra note 20, at 358. 
coastal area covered by the CAMA is a collaborative effort of the state and the local governments involved. The state, through the Coastal Resources Commission, has the authority to designate specific "areas of environmental concern"; ${ }^{25}$ in addition, the Commission formulates guidelines for the coastal planning required of local governments, whose plans must be reviewed and approved by the Commission. ${ }^{26}$ At this writing the planning guidelines have been promulgated and use plans are being formulated, but action has been deferred on the final designation of areas of environmental concern pending receipt of the recommendations by the local governments. ${ }^{27}$

Despite the inconipleteness of the planning process, however, a fairly precise idea of the content of the local land use plans can be gleaned from the planning guidelines. Each land use plan is to consist of five elements: (1) a statement of local land use objectives, policies, and standards, (2) a summary of data collection and analysis, (3) a map of existing land use, (4) a land classification map, and (5) a written text describing appropriate development for proposed areas of environmental concern. ${ }^{28}$

The policy element of the plan must take into account population projections, economic trends, the provision of housing and services, and the protection of natural environments to arrive at a general statement of what type of community is desired for the future. This is to be used to guide future development, to set priorities for action, and to give necessary background information for land classification. ${ }^{28}$

Data collection and analysis are necessary for the formulation of policies. This begins with a review and mapping of existing land use patterns. Then an analysis of carrying capacity is required, which must take into consideration not only natural constraints on development, such as physical limitations (hazard areas, soil limitations, and water supply), fragile areas (wetlands, wildlife habitat, beaches, and scenic areas), and resource potential (productive woodlands and agricultural areas), but also institutional restraints, such as design capacity of existing water and sewage facilities and roads. Anticipated demand for land is then calculated on the basis of population and economic trends. Some

25. N.C. Gen. StAT. \$§ 113A-113, -115 (1975).

26. Id. $\$ \S 113 \mathrm{~A}-109,-110$. The deadline for the preparation and adoption of the local land use plans has been extended to 480 days (from 300 days) after January 27, 1975. Id. § 113A-109 (Supp. 1975).

27. See Guidelines for Local Planning in the Coastal Area Under the Coastal Area Management Act of 1974, adopted by the Coastal Resources Commission of North Carolina on January 27,1975 , and amended on October 15, 1975, at 14.

28. Id. at 24 .

29. Id. at $25-26$. 
prediction then can be made of future land needs in particular use categories as well as of future demand for community facilities. ${ }^{30}$

Using this analysis as background, the planning guidelines also require the classification and mapping of all lands within the jurisdiction into five broad categories: developed (lands of moderate to high population density), transition (lands where population density will be accommodated through the provision of the necessary public services), community (lands with present or predicted low density development which will not require extensive public services), rural (lands whose highest use is for forestry, agriculture, or other resource use, as well as lands for future needs currently recognized), and conservation (fragile, hazard, and other lands necessary for a liealthy environment). ${ }^{31}$ Local jurisdictions may also formulate detailed land use maps together with the land classification map, but this is not required. ${ }^{32}$ Despite the fact that separate land use plans will be prepared by each local jurisdiction, a single comprehensive plan will emerge since the Coastal Resources Commission lias the responsibility of coordinating the individual plans. $^{33}$

The local governments may also delineate the specially protected "areas of environmental concern," 34 but this does not serve as a designation for purposes of granting permits. Areas of environmental concern will be designated by the Commission through the adoption of written descriptions of such areas; ${ }^{35}$ the Commission is also studying the possibility of mapping sucli areas. ${ }^{36}$

\section{B. Implementation: The Legal Effect of Planning}

Unlike the management programs in effect in Oregon and Florida (which have stringent consistency provisions requiring zoning, subdivision decisions, and all state and local government regulatory actions to

30. Id. at $26-35$.

31. Id. at $33-43$.

32. Id. at 24 .

33. Id. at 12. The coastal plan is subject to review and revision by the local governments and the Commission prior to its adoption. N.C. GEN. STAT. § 113A-110 (1975).

34. The categories of lands and waters that may be designated as areas of environmental concern are coastal wetlands, estuarine waters, renewable resource areas like watersheds or aquifers or prime forestry land, fragile historic or natural resource areas, areas subject to public rights, and natural hazard areas. N.C. GEN. STAT. § 113A-113 (1975); Guidelines for Local Planning, supra note 27, at 50. Such areas overlap with the land classification system, but policies and regulations concerning them will take precedence over policies concerning the land classifications. Id. at 39.

35. N.C. GEN. STAT. § 113A-113 (1975).

36. Guidelines for Local Planning, supra note 27, at 48. 
be in accord with the required comprehensive land use plans), ${ }^{37}$ the North Carolina CAMA provides for only partial legal effectiveness of the plan. ${ }^{38}$ Lands and waters which are determined to be areas of environmental concern are subject to direct control by the state: development cannot take place within such areas without a permit. ${ }^{39}$ Local governments may assume responsibility for granting permits for "minor developments" 40 within those areas, but their implementation and enforcement programs are subject to state-level review. ${ }^{41}$ No permit for development within an area of environmental concern may be issued unless it is consistent with the approved land use plan, and existing local ordinances and regulations affecting an area of environmental concern must be modified to be consistent with the plan. ${ }^{42}$

On the other hand, the coastal management plan has no legal effect insofar as lands and waters outside these designated areas are concerned. The implementation of the plan is up to the local governments; the state has the power only to review local ordinances and regulations for consistency and to transmit nonbinding recommendations. ${ }^{43}$ In addition, state-level regulation and decisions under legislative authority apart from the CAMA are not required to be consistent with the plan, even within the areas of environmental concern. The only requirement is that existing state regulatory programs be administered "in coordination and consultation with . . . the [Coastal Resources] Commission."

It is obvious that this lack of enforceability is the Achilles' heel of North Carolina's emerging coastal zone management program. Unless

37. Ch. 75-257, [1975] Fla. Laws 663; OrE. Rev. STat. §§ 197.175-.185 (1973).

38. An earlier draft of the CAMA which was prepared by the author would have provided for complete consistency between local and state land use and regulatory decisions and the coastal land use plan, but this was rejected by the North Carolina General Assembly. See Schoenbaum, Public Rights and Coastal Zone Management, Appendix $\$ 6(7), 51$ N.C.L. REV. 1, 36 (1972)

39. N.C. GEN. STAT. \& 113A-118 (1975).

40. Id. \$ 113A-121. A minor development is defined as any development other than a "major development." Id. § $113 \mathrm{~A}-118$ (d)(2). A "major development" is any development which requires a state license or permit, which occupies a land or water area in excess of twenty acres, which contemplates drilling for or excavating natural resonrces on land or under water, or which consists of a structure in excess of 60,000 square feet. Id. \$113A-118(d)(1).

41. Id. § 113A-117 (Supp. 1975).

42. Id. § 113A-111 (1975). In effect, then, the "area of environmental concern" designation creates a new state-level permit program which overlaps local government zoning and subdivision regulation. The latter ordinances still operate within those areas but cannot be inconsistent with the policies in the CAMA. If the areas are mapped, a new district which overlaps existing zoning districts will be created.

43. Id.

44. Id. $\S 113 \mathrm{~A}-125(\mathrm{~b})$. 
corrected, this weakness will not only allow the carefully developed plans to go for naught; uncontrolled development in other parts of the planning area will also create irresistible pressures on the areas of environmental concern, thus undermining the effectiveness of that portion of the management program as well. Analogous problems exist in the coastal zone management programs of other states. ${ }^{45}$ To overcome this fatal weakness, it is imperative that action be taken to develop a land use guidance system to implement coastal planning.

\section{A Management System to Implement Planning}

Restrictions on development in environmentally critical areas, directly enforced by the state, are characteristic of many state programs, ${ }^{46}$ but they are imadequate for implementation of a coastal management plan. Those restrictions must be supplemented on the local, state, and federal levels by a coordinated land use guidance system that respects the integrity of the plan. Such a guidance system can include traditional as well as newer forms of land use regulation. It should be recognized that each regulatory tool, considered individually, will have significant weaknesses that may have to be compensated for by other mechanisms.

A. The Function of Traditional Forms of Land Use Controls: Zoning, Subdivision Regulation, and Capital Improvement Budgeting

The traditional approach to land use planning in the United States consists of projecting economic and population growth, formulating a capital improvement plan for the construction necessary to accommodate the expected growth, and relying on zoming and subdivision regulation to design the resulting pattern of land use. Zoning, which long ago was upheld against constitutional challenge by the United States Supreme Court, ${ }^{47}$ is traditionally used to divide a jurisdiction into districts and to prescribe regulations controlling the height and bulk of structures, lot coverage and open space, density of population, and the land uses permitted within each district. ${ }^{48}$ Conventional subdivision

45. For example, in California the implementation of the Coastal Zone Conservation Plan will require additional action by the state legislature. CaL. Pub. Res. Code $\S \S 27300,27304$ (e) (West Supp. 1975).

46. See, e.g., California Coastal Zone Conservation Act of 1972, CaL. PuB. Res. CoDE $\$ \S 27000$ et seq. (West Supp. 1975); The Florida Environmental Land and Water Management Act of 1972, FLA. Stat. ANN. $\$ 380.012$ et seq. (1974); Coastal Public Lands Management Act of 1973, Tex. Rev. Crv. Stat. art. 5415e-1 (Supp. 1973).

47. Euclid v. Ambler Realty Co., 272 U.S. 365 (1926).

48. U.S. Dep'T of Commerce, A Standard State Zoning Enabling Act (1926). 
requirements operate only at the moment when raw land is converted to building sites. They supplement zoning by requiring the dedication and proper specifications of streets, minimum lot sizes, and provision for water, sewer, and other public utilities. ${ }^{48}$

Most of the cities and counties within the coastal area of North Carolina have enacted zoning and subdivision controls. ${ }^{50}$ All either have employed full-time planning staffs or rely on outside consultants or the state Department of Natural and Economic Resources for technical planning assistance. Existing zoning ordinances are very nuch alike. The boundaries of about ten different "use districts" are drawn on an official zoning map. ${ }^{51}$ Within each district certain named uses are

49. The North Carolina General Assembly has granted zoning and subdivision regulation powers separately to counties, N.C. GEN. STAT. §§ 153A-340 to -347 (1974), and municipalities, id. $\$ \S 160 \mathrm{~A}-381$ to $-392(1972)$. In 1973 , thirty-nine of the one hundred counties and 228 municipalities (fifty-one percent of the state total) in North Carolina had enacted zoning ordinances. Local ordinances passed pursuant to this delegation of authority enjoy a presumption of validity. State v. Joyner, 286 N.C. 366,211 S.E.2d 320 (1975); Orange County v. Heath, 278 N.C. 688 , 180 S.E.2d 810 (1971). However, they may not unduly restrict the private use of land so as to deprive the owner of all practical uses of his property, or of the only use to which it is reasonably adapted. Roberson's Beverages, Inc. v. City of New Bern, 6 N.C. App. 632, 637, 171 S.E.2d 4, 7 (1969); Helms v. City of Charlotte, 255 N.C. 647, 653, 122 S.E.2d 817, 822 (1961). The enabling legislation sets out the purposes for which zoning is exercised. N.C. GEN. STAT. \$ 153A-340 (1974) (counties), id. \$ 160A-381 (1972) (cities and towns). It is also required that zoning restrictions be "in accordance with a comprehensive plan." Id. \$ 153A-341 (1974) (counties), id. § 160A-383 (1972) (cities and towns). The intent of this provision is to ensure that zoning ordinances be a logical outgrowth of the community planning and development process. In North Carolina, however, the zoning ordinance itself has been found to fulfill this requirement; no extrinsic master plan is necessary to withstand legal attack. Allred v. City of Raleigh, 7 N.C. App. 602, 607, 173 S.E.2d 533, 536 (1970), rev'd on other grounds, 277 N.C. 530, 178 S.E.2d 432 (1971). The view of the North Carolina courts on this issue stands in contrast with recent decisions in a few jurisdictions which require zoning to conform to the principles of an extrinsic master plan. See, e.g., City of Louisville v. Kavanaugh, 495 S.W.2d 502 (Ky. 1973); Udell v. Haas, 21 N.Y.2d 463, 235 N.E.2d 897, 288 N.Y.S.2d 888 (1968); Fasano v. Board of County Comm'rs, 264 Ore. 574, 507 P.2d 23 (1973).

50. Most counties have zoned only a part of their territorial jurisdiction, however, as permitted under N.C. GEN. STAT. \$ 153A-342 (1974).

51. For example, the Currituck County zoning ordinance provides the following categories of use districts: residential-agricultural, residential-suburban, residential-multiple dwelling, community shopping, highway commercial, light industrial, heavy industrial, recreation-residential, recreation-commercial, and flood-plain. Currerrck County, N.C., Zoning Ordinance $\$ 80$ (1971). A zoning plan is coinposed of at least two parts, a map showing district boundaries and a text describing the ordinance. N.C. GEN. STAT. § 153A-344 (1974) (counties), id. § 160A-387 (Supp. 1975) (cities and towns). Once drawn up by the planning agency, the zoning plan must be formally adopted by the board of county commissioners or the city council, which are also responsible for amendments and supplements to the zoning plan. Id. § 153A-343 (1974) (counties), id. $\$ 160 \mathrm{~A}-384$ (1972) (cities and towns). Once the zoning ordinance is 
permitted by right; other named uses are permitted if the Board of Adjustment finds that particular prescribed conditions will be met. ${ }^{.2}$ In addition, dimensional requirements are prescribed for developments in each category of uses. These are usually minimum lot sizes, minimum required lot area and setback for improvements, building heights, and off-street parking requirements..$^{53}$ Extractive uses such as quarrying and the removal of sand and gravel are typically allowed by right in industrial districts and as a special use in other districts. ${ }^{54}$ Licenses may be required for mobile homes which, in addition, are required to meet specified conditions. ${ }^{55}$ Beach access is provided in some ordinances through requirements that any road designed at angles other than parallel to a public recreation-resource must be mapped to the boundary of the resource and that large developments involving more than 600 feet of recreation-resource frontage must provide public pedestrian access from the roadway to the recreation area. ${ }^{56}$

Existing subdivision ordinances in coastal jurisdictions in North Carolina are intended to regulate the internal development of particular building sites and to supplement the area's capital improvements budget by ensuring that minimum design standards for streets, utilities, and other community services are met. Although North Carolina enabling

certified by the local governing body, it has the force and effect of a valid police power regulation.

52. The authority of the Board of Adjustment to issue special or conditional use permits is derived from N.C. GEN. STAT. \& 153A-340 (1974) (counties); id. \& 160A-381 (1972) (cities and towns). The Board must grant the permit if the applicant meets the standards set out by the ordinance, and it cannot deny a permit solely because of adverse impact on "the public interest": it must rely on specific standards, because the counties and municipalities have no power to delegate the definition of the public interest. Jackson v. Guilford County Bd. of Adjustment, 275 N.C. $155,167,166$ S.E.2d 78, 86 (1969). However, the Board may impose reasonable and appropriate conditions and safeguards on these permits, N.C. GEN. STAT. $\$ 153 A-340$ (1974) (counties); id. $\S 160 \mathrm{~A}-381$ (1972) (cities and towns). In addition, some of the ordinance requirements for a special use permit may not be susceptible to precise definition, and therefore may be stated in general terms, conferring a degree of discretion upon the decision-making authority. Humble Oil \& Refining Co. v. Board of Aldermen, 284 N.C. 458, 471, 202 S.E.2d 129, 138 (1974). The Board of Adjustment also exercises some discretion in considering applications for variances. The zoning ordinance is enforced by a local government official, usually the building inspector or zoning adininistrator. The enabling statute grants cities and towns the power to seek injunctive relief to prevent violation of zoning ordinances. N.C. GEN. STAT. \&160A-389 (1972). Curiously, counties are not specifically granted this power, although injunctive relief would appear to be available under general equitable principles.

53. N.C. GEN. STAT. \& 153A-340 (1974) (counties); id. § 160A-381 (1972) (cities and towns).

54. See, e.g., CuRrutuck CounTY, N.C., Zoning ORdINANCE $\$ 101$ (1971).

55. Id. $\$ 100$.

56. Id. 896 . 
legislation authorizes counties and cities to require that the subdivider dedicate streets, utility rights of way, and recreational areas for residents of the immediate neighborhood, ${ }^{57}$ the typical local ordinance provides only for the first two types of dedication while merely recommending the dedication of recreational areas. ${ }^{58}$ Many jurisdictions have enacted planned unit developinent ${ }^{59}$ ordinances which give the planning commission the discretion to vary subdivision regulations in the case of a coinplete group development whicl provides "adequate" public spaces and improvements and which also provides binding assurance of the achievement of the plan. ${ }^{60}$

It is clear that reliance solely on the foregoing legal devices to implement the new type of planning required under the CAMA would be disastrous. Conventional zoning and subdivision regulation assume that an essentially unlimited supply of land suitable for urbanization exists. ${ }^{61}$ The system divides and regulates the use of land in an effort to provide the most desirable living and working conditions for the individual; the land resource itself is not the focus of attention. The capacity of the land to support development is considered less important than the compatibility of land uses with one another. Since the passage of the first zoning ordinances, local governments have altered the basic zoning framework somewhat by increasing the complexity of the regulations within a larger variety of land use classification; ${ }^{62}$ however, the focus has remained on existing use patterns and projected deinand directions rather than on environinental carrymg capacity. An additional problem with zoning as the basic land use tool is its assumption that rigid use categories can be maintained for an indefinite time. It has been demonstrated that this assumption is erroneous. ${ }^{63}$ Even the best zoning plan is typically overtaken by events. Unexpected development pressures cause ever-increasing use of the variance, the zoning amendnient, and the

57. N.C. GEN. Stat. $\$ 1153 A-330$ (1974); id. § 153A-331 (Supp. 1975) (counties); id. $\$ 160 \mathrm{~A}-371$ (1972); id. $\$ 160 \mathrm{~A}-372$ (Supp. 1975) (cities and towns).

58. See, e.g., Currituck CountY, N.C., Subdivision Regulations arts. IX, XIII (E) (1971).

59. For a discussion of planned unit developments, see text accompanying notes 75 77 infra.

60. See, e.g., CuRrituck CounTY, N.C., Subdivision Regulations art. X(A) (1971).

61. See E. Kaiser, K. Elfers, S. Cohn, et al., Promoting Environmental QualITY Through URban Planning and Controls 95-97 (Environmental Protection Agency Grant R801376, 1973).

62. Task Force on Land Use and Urban Growth, The Use of Land: A CitiZEN's Policy GuIDE to URBaN Growth 183 (1973).

63. Id. at $187-89$. 
special use procedures, to the point where there is little relation between the zoning plan and the actual physical make-up of the community. ${ }^{64}$

This does not nean, however, that zoning should be discarded as a tool in coastal zone nuanagenent. Rather, its limitations should be recognized and supplementary managenent techniques devised to neet implementation problems that traditional zoning was never intended to fulfill. Zoning should also be adapted to the new kind of regional environmental planning required under the CAMA.

Several changes in the zoning process are necessary to make it an instrument to implement planning. ${ }^{65}$ First, each local government should, simultaneously with the adoption of the coastal nuanagement plan, pass a zoning plan that is consistent with the land classification systen required under the coastal management plan. This zoning plan would provide a detailed land use map that would be more specific than the coastal management plan inap, and would guide the implementation of the general classification categories.

Second, since the land classification system set forth in the coastal area management guidelines calls for conservation and resource preservation areas, ${ }^{\beta 6}$ while the typical zoming ordinance contains only developmental classifications, ${ }^{07}$ new zoning districts must be created that correspond with the conservation classifications. Zonimg ordinances should thus include flood plain, shoreland, wetland, historical forest, watershed, and wildlife habitat districts. ${ }^{88}$ The purpose for these new districts need not necessarily be to prohibit all development or to maintain the areas in a totally natural condition. ${ }^{99}$ The intent would be to restrict and

64. Council on Enytronmental Quality, Fifth ANNual Report 52 (1974); cf. Brough, Flexibility Without Arbitrariness in the Zoning System: Observations on North Carolina Special Exception and Zoning Amendment Cases, 53 N.C.L. REv. 925, 925-26 (1975).

65. These changes in zoning should be accompanied by a limited requirement for environmental impact statements. See text accompanying notes $88-97$ infra.

66. See text accompanying note 31 supra.

67. See note 51 supra.

68. Certain of these new categories of districts would, of course, overlap and could be combined.

69. Governmental regulation of private property must not, uuder the CAMA, so restrict the use of property as to deprive the landowner of the "practical use" of his property. N.C. GEN. STAT. $\$ 113 A-123$ (1975). This statutory test for the taking of private property without compensation was taken from the case of Helms v. City of Charlotte, 255 N.C. 647, 122 S.E.2d 817 (1961). Under the "practical use" test, however, there is no reason why a court should look only at practical uses that are possible through alteration of the natural state of the lands involved; "practical use" also includes possible natural state uses of the lands in question. Cf. Just v. Marinette County, 56 Wis. $2 d$ 7, 17-18, 201 N.W.2d 761, 768 (1972). See also Glenn, supra note 20, at 33638. 
condition uses in order to protect the resource involved. Accordingly, no use should be permitted as of right in such districts. The types of uses would be restricted, and all uses would be conditional and thus subject to case-by-case review. Specific use conditions based on the environmental carrying capacity of each type of district could be drafted and included in the ordinance. In addition, all uses in such districts should be subjected to a pre-development environmental impact analysis, ${ }^{70}$ and the Board of Adjustment should have the power to impose additional conditions in connection with the granting of a permit. ${ }^{71}$

There is precedent for such an approach. For example, the zoning ordinance of Currituck County, North Carolina, contains a "flood plain" district designation, ${ }^{72}$ in which no uses are permitted as of right. The basic aim of the district is to maintain the barrier dunes and shoreland vegetation free of all encroachment 500 feet shoreward of the mean high water mark. ${ }^{73}$ This basic approach should be expanded to include additional categories of districts. Authority for the creation of such new districts can be derived from the general grant of power in state enabling legislation to promote "health, safety, inorals, or the general welfare of the community," " but to remove all doubt, it would be desirable that the state enabling act be amended to recognize the preservation of environmental values as a valid zoning purpose.

Third, authority for a cluster zone or planned umit development (PUD) should be provided in local government zoning ordinances and subdivision regulations. The PUD has been defimed as

an area of land, controlled by a landowner, to be developed as a single entity for a number of dwelling units, and commercial and industrial uses, if any, the plan for which does not correspond in lot size, bulk or type of dwelling or commercial or industrial use, density, lot coverage and required open space to the regulations established in any one or more districts created ... under the provisions of a mumcipal zoning ordmance enacted pursuant to the conventional zoning enabling act of the state. ${ }^{75}$

70. See text accompanying notes 88-97 infra.

71. This authority is already a feature of local zoning ordinances of coastal jurisdictions. See, e.g., Currituck CounTY, N.C., Zoning Ordinance $\$ 64.3(\mathrm{e})$ (1971).

72. Id. $\$ 98$. It should also be noted that North Carolina has established a statewide program to delineate floodways and to regulate development in them. A local government permit is required for any construction in the floodways, other than for certain statutorily specified uses. N.C. GEN. STAT. § 143-215.54 (1974). Cities and counties in North Carolina are also authorized to designate, as a part of a zoning ordinance, "historic districts either as separate use-districts or as districts which overlap other zoning districts." Id. $\$ 160 \mathrm{~A}-395$ (Supp. 1975).

73. CURRITUCK COUNTY, N.C., Zoning ORdinance $\$ 98$ (1971).

74. N.C. GEN. STAT. $\$ 160 A-381$ (1972) (cities); id. $\$ 153$ A-340 (1974) (counties).

75. U.S. ADVISORY COMmission ON INTERgovernmental Relations, 1970 CUMU- 
The PUD technique generally allows such developments to have clusters of increased density combined with provisions for open space; it provides flexibility since the actual design is a matter of negotiation between the developer and planning authorities. Four varieties of planned unit development have been identified: (1) the density transfer, (2) the mixed residential development without density increases, (3) the mixed residential development with density increases, and (4) inixed uses. Although the PUD is theoretically applicable to projects of any size and to low-incoine as well as luxury housing, it is most attractive to developers of large tracts. Generally speaking, the PUD process has been undertaken in jurisdictions having long experience with planning and zoning techniques, large and competent planning staffs, and specific enabling authority. The PUD system should not be considered a primary land use tool for a coastal county with little experience in the field of developmental control. This inechanism may, however, have greater value for the government capable of utilizing it. Planned umit development offers the advantage of clustering growth in areas capable of supporting population and structures. And, by increasing density in some locations, the technique can provide more open space. Clustering also permits inore efficent provision of urban services to an area of limited size. Energy use is also curtailed. ${ }^{78}$

Although several coastal jurisdictions in North Carolina have PUD ordinances, their validity has never been tested in the North Carolina courts, and they are not specifically authorized in the zoning enabling act. One commentator, after reviewing the case law, has concluded that, although PUD ordinances may be upheld even in the absence of a zoning enabling provision, appropriate enabling legislation is needed on the state level to remove all doubt as to the validity of this device. ${ }^{77}$

Fourth, the coastal management plan, when adopted by local governments, should be considered, in effect, a constitution to which future zoning decisions must conform. In this way, zoming would assume a proper relationship to planning: the plan would provide policy determination and guiding principles, while the zoming ordinance would

iative ACIR State Legislative Program 31-36-00, at 5 (1969), quoted in D. Hagman, Urban Planning and Land Development Control. LaW 431 (1971).

76. See Real Estate Research Corporation, The Costs of Sprawl-Literature REVIEW AND BIBLIOGRAPHY 28-43 (1974).

77. Comment, Planned Unit Development and North Carolina Enabling Legislation, 51 N.C.L. Rev. 1455, 1477-78 (1973). For an excellent summary of the necessary elements of such enabling legislation see Sternlieb, Burchell, Hughes, et al., Planned Unit Development Legislation: A Summary of Necessary Considerations, 7 URBAN L. ANNUAL 71 (1974); for an analysis of case law, see Comment, Judicial Interpretation of the Planned Development Statute in Pennsylvania, 9 URBAN L. ANNual 273 (1975). 
provide detailed means for its implementation. The plan would have immediate effect in the community, changing land market values. Applications for zoning changes and variances should be judged by decision-making bodies on the basis of their fidelity to the specific criteria of the plan. Zoning decisions should be reviewed by the courts for their reasonableness im relation to the plan as well as for their conformity to due process standards. ${ }^{78}$

Each local jurisdiction should thus amend its zoning ordinance to require that decisions be consistent with the plan adopted under the CAMA. Even in the absence of sucl action, however, the courts may require that zoning conform to coastal land use planning. Although in North Carolina zoning has been lield to be a self-contamed activity, requiring no conformity to an extrinsic master plan, ${ }^{79}$ this view may change with the passage of the CAMA since local governments in coastal areas must now adopt an extrinsic master plan separate from the zoning process. The North Carolina courts may follow the trend in a growing minority of jurisdictions toward granting legal status or even controlling weight to the planning docunent and requiring zoning decisions to conform, or at least be reasonably related, to the niaster plan..$^{80}$

Similarly, local capital investment policies and subdivision ordinances should be required to conform to the adopted coastal land use plan. Standards for land subdivision should ensure that growth does not outstrip community infrastructure planning. Dedication of land for recreation should be required, as permitted by the North Carolina enabling statute. ${ }^{81}$ Particular attention slrould be given to adequate,

78. For an exposition and an argument in favor of a limited judicial role, see Tarlock, Consistency With Adopted Land Use Plans as a Standard of Judicial Review: The Case Against, 9 URBan L. ANnual 69 (1975).

79. Allred v. City of Raleigh, 7 N.C. App. 602, 173 S.E.2d 533 (1970), rev'd on other grounds, 277 N.C. 530,178 S.E.2d 432 (1971).

80. See, e.g., City of Louisville v. Kavauaugh, 495 S.W.2d 502 (Ky. 1973); Aspen Hill Venture v. Montgomery County Couucil, 265 Md. 303, 289 A.2d 303 (1972); Fasano v. Board of Couuty Comm'rs, 264 Ore. 574, 507 P.2d 23 (1973). One article distinguishes two variants of the minority view: the planning mandate theory, which requires consistency between local regulatory action and an extrinsic master plan, and the planning factor doctrine, which allows land use decisions to be examined in light of the standards and policies set out in the planning document. Sullivan \& Kressel, Twenty Years After-Renewed Significance of the Comprehensive Plan Requirement, 9 URBAN L. ANNUAI 33, 41 (1975). An early proponent of the idea that zoning should be faithful to an extrinsic comprehensive plan was Professor Charles M. Haar. See Haar, "In Accordance with a Comprehensive Plan," 68 HARv. L. REv. 1154 (1955).

81. N.C. GEN. STAT. \& 153A-331 (Supp. 1975) (counties); id. § 160A-372 (cities and towns). 
bonded ${ }^{82}$ water supply and sewage disposal facilities, storm water drainage, and the mitigation of damage to topographical and natural features. Where feasible, the developer should be required to leave a minimum percentage of the natural vegetative cover undisturbed..$^{83}$

Some local jurisdictions may want to go beyond this and regulate not only the location but also the timing and sequence of development, through the zoning, subdivision, and capital budgeting mechanisms. For example, the village of Ramapo, New York, a suburb of New York City, has placed all residential development under special permit requirements framed in terms of the availability of five categories of public services, and the San Francisco suburb of Petaluma has limited the number of new residential umits to 500 per year for a five year period. ${ }^{84}$ It must be recognized, however, that such techniques may not be suitable for the coastal zones of other states where socio-economic and environmental conditions are markedly different from those in the suburban areas of New York and San Francisco. Most coastal areas of North Carolina, for example, have a relatively stable population, ${ }^{85}$ high unemployment with an attendant need for economic growth, ${ }^{86}$ and a development

82. Where required utilities or improvements have not been completed prior to the submission of the subdivision plan for final approval, the developer should be required to post a performance bond or some other fimancial guarantee of the installation of improvements. See, e.g., Curritucr County, N.C., Subdivision Regulations art. XII (C) (2) (1971).

83. This requirement may arguably be imposed under the authority of existing law which allows subdivision regulations to create conditions essential to public health, safety, and the general welfare, N.C. GEN. STAT. § 153A-331 (Supp. 1975) (counties); id. $\S 160 \mathrm{~A}-372$ (cities and towns). To remove all doubt as to the validity of such a requirement, however, North Carolina's subdivision regulation legislation should be amended to give specific authority for protection of the natural environment.

84. These ordinances, which typify the spate of new local growth management laws, have withstood constitutional attack. See Golden v. Planning Bd., 30 N.Y.2d 359, 285 N.E.2d 291, 334 N.Y.S.2d 138 (1972), appeal dismissed, 409 U.S. 1003 (1972); City of Petaluma v. Construction Indus. Ass'n, 522 F.2d 897 (9th Cir. 1975). For a discussion of the constitutional issues involved, see Juergensineyer \& Gragg, Limiting Population Growth in Florida and the Nation: The Constitutional Issues, 26 U. FLA. L. REV. 758 (1974). There are, however, continuing doubts in the state courts as to the reasonableness of ordinances regulating the timing and sequence of development. See Board of Supervisors v. Horne, - Va.,- 215 S.E.2d 453 (1975); Board of Supervisors v. Allman, 215 Va. 434, 211 S.E.2d 48 (1975).

85. For example, the population of Carteret County, which because of the presence of one of North Carolina's major ports and its attractiveness for recreation should be a high-growth area, experienced a population increase of only 4,195 persons or fifteen percent from 1960 to 1970 (27,438 to 31,603). D. GodschalK, F. PARKer \& T. KNoche, supra note 9, Appendix A, at 1-2. Growth pressures stem largely from second home development. Id.

86. Id. at 100 . 
process that, except in a few areas, is largely characteristic of a lowdemand area. ${ }^{87}$

\section{B. Environmental Impact Analysis as a Supplement to the Zoning Process}

Although the foregoing proposed reforms of the zoning, subdivision, and capital budgeting mechanisms would aid the implementation of the coastal zone management program, additional problems remain. First, the zoning process is not designed to gather information about the impact of development on environmental carrying capacity. Second, zoning is essentially pre-regulation; the most carefully prepared zoning map may be overwhelmed by variances, zoning amendments, and special exceptions that are granted on a case-by-case basis. These deficiencies can be corrected by requiring that significant land use decisions involve a review of the environinental consequences of the proposed action. ${ }^{88}$ A land use decision should be considered significant if it involves a variance, zoning amendment, conditional use permit, special exception, subdivision approval, or any "major developinent project."89 Environinental impact review can thus supplement the zoning and subdivision reforms suggested above. ${ }^{90}$

Environinental impact analysis would have two basic purposes: (1) full disclosure of the impact of the development on the carrying capacity of the land and on the objectives and primciples of coastal planming, and (2) the guidance of substantive decision-making and the development of conditions and restrictions to preserve acceptable levels of environmental and institutional carrying capacity, as well as to protect the integrity of the plan. It would also provide a basis for judicial review of local land use decision-making. The use of this process presupposes, of course, that the local community, operating under the planning guidelines promulgated by the Coastal Resources Commission, has made a political value judgment regarding the protection of minimum levels of carrying capacity for environmental systems, and has implemented these values through the processes described above, namely, the coordination of zoning with the coastal land use plan and the creation of new zoning districts with specific carrying capacity guide-

87. Id. at 82 .

88. See TASK Force ON LAND USE AND URBAN GRowth, supra note 62, at 208-11.

89. See, e.g., N.C. GEN. STAT. §§ 113A-1 to -10 (1975). "Major development projects" are defined as including but not limited to shopping centers, subdivisions, and other housing developments, as well as industrial and commercial projects, except for projects of less than two contiguous acres in extent. $1 d$. $\$ 113 \mathrm{~A}-9(1)$.

90. See text accompanying notes 65-83 supra. 
lines for floodways, wetlands, historic areas, forests, and complex natural areas. ${ }^{.1}$ It also depends on the exercise of some degree of discretion by the relevant decision-making authority. ${ }^{92}$

The environmental review process should be constructed so that it does not unduly burden landowners and developers. A checklist form, no longer than two sides of one sheet of paper, should be developed to be completed and submitted along with the zoning permit application. The developer would be required merely to state impact factors sucl as water use, water discharge, number of units, present vegetative cover, land clearing required, wetland filling or dredging, dune disturbance, soil characteristics, and energy use requirements. The planning board or board of adjustment should be empowered to require more information where necessary.

The implementation of a local government environmental impact assessment process would, of course, have to be authorized under state law. The North Carolina Environmental Policy Act, for instance, authorizes the governing bodies of all cities, towns, and counties to require detailed environmental impact statements of any special purpose

91. It is contemplated that the local zoning ordinance would specify that no use shall be by right in such areas, thus subjecting all proposed uses to environmental review. See text accompanying notes 66-71 supra.

92. It should be pointed out, however, that under North Carolina law there are substantial limits to the discretionary function of decision-making bodies regarding devices which induce flexibility into the zoning system. A zoning amendment may be invahdated if it is viewed by the court as "spot zoning" that arbitrarily places the subject property in a different use zone from that to which the surrounding property is subject or if it is seen as "contract zoning" that arbitrarily benefits a particular landowner. Blades v. City of Raleigh, 280 N.C. $531,549-51,187$ S.E.2d 35, $45-47$ (1972); see Allred v. City of Raleigh, 277 N.C. 530,178 S.E.2d 432 (1971). The exercise of the special exception power has been declared invalid where the board of adjustment or commissioners were required by the ordinance to determine the impact of the grant of a permit on the "public interest" on the ground that this was an unconstitutional exercise of discretion unaided by prestated standards. In re Ellis, 277 N.C. 419, 178 S.E.2d 77 (1970); Jackson v. Guilford County Bd. of Adjustment, 275 N.C. 155, 166 S.E.2d 78 (1969). On the other hand, it is clear that in the exercise of the special exception power, the Board of Adjustment may attach conditions to the special use permit. N.C. GEN. STAT. § 160A-381 (1972); id. $§ 153$ A-340 (1974). Moreover, the North Carolina Court of Appeals has upheld the validity of an ordinance that required the board passing on the application for a special use permit to consider whether the use "will not materially endanger the public health or safety" and "will be in harmony with the area in which it is located," and the North Carolina Supreme Court affirmed. See Humble Oil \& Refining Co. v. Board of Aldermen, 284 N.C. 458, 471, 202 S.E.2d 129, 138 (1974), aff'g 17 N.C. App. 624, 628, 195 S.E.2d 360, 363 (1973). For a discussion of the cases and an argument that the North Carolina Supreme Court has, in some cases, placed unwarranted limits on the exercise of discretion by zoning bodies, see Brough, supra note 64 . For an analysis of the value of flexible zoning techniques in Ohio, see Peterson, Flexibility in Rezonings and Related Governmental Land Use Decisions, 36 Oно ST. L.J. 499 (1975). 
unit of government as well as any private developer for "major developments," which are defined as imcluding virtually all projects at least two acres in extent. ${ }^{93}$ This authority has been utilized by only two local governments in the state. ${ }^{94}$ The Environmental Policy Acts of at least four other states require environmental impact statements of local governments. ${ }^{95}$ The law of one of these states, California, has been imterpreted by the state's highest court to require the impact statement process in connection with a local government's grant of conditional use and building permits when the project would have a significant effect on the environment. ${ }^{96}$

It would appear, however, that the full environmental impact statement process that is designed for evaluation of governmental actions would not be appropriate for private developers. It is too burdensome and expensive to be a practical tool. But the advantages of the assessment technique should not be overlooked. ${ }^{27}$

\section{State and Federal Regulatory and Program Activities: Permit Coordination and Plan Revision}

Many state and federal regulatory programs established to exercise control over coastal resources will continue to operate after a coastal area management program has been established. These imclude statefederal regulation of water and air quality, ${ }^{98}$ wetland protection legisla-

93. N.C. Gen. Stat. \$ 113A-8 to -9 (1) (1975). See note 89 supra.

94. Holden Beach, N.C., Ordinance Requiring Environmental Impact Statement, 1972; Transylvania County, N.C., Ordinance to Establish an Environmental Policy, Jan. 28, 1975.

95. See Yost, NEPA's Progeny: State Environmental Policy Acts, 3 ENVIRONMENTAL L. REP. 50090, 50093 (1973).

96. Friends of Mammoth v. Board of Supervisors, 8 Cal. 3d 247, 502 P.2d 1049, 104 Cal. Rptr. 761 (1972).

97. Accordingly, it is proposed that the North Carolina Environmental Policy Act be amended to eliminate the authorization for local governments to require detailed impact statements from private developers, and to substitute a requirement that local governments get a short-form environmental assessment from private developers in the case of significant land use decisions and consider such assessment as an integral part of their decision-making process. Even absent such a specific legislative mandate, however, local governments would appear to possess the appropriate authority to implement this process under existing state zoning enabling legislation. See Humble Oil \& Refining Co. v. Board of Aldermen, 284 N.C. 458, 202 S.E.2d 129 (1974); N.C. GeN. Stat. \$ 160A4 (1972).

98. In North Carolina, the Environmental Management Commission is primarily responsible for admimistering the state's programs of water and air pollution control, which have been established pursuant to the Federal Water Pollution Control Act, 33 U.S.C. §§ 1251 et seq. (Supp. III, 1973), and the Federal Clean Air Act, 42 U.S.C. $\$ \S 1857$ et seq. (1970). See N.C. Gen. STAT. $\$ \S 143-215$ to -215.1 (Supp. 1975); id. $\$ 143$ 215.108. 
tion, ${ }^{00}$ sand dune preservation, ${ }^{100}$ flood plain regulation, ${ }^{101}$ and controls on excavating or filling within navigable waters. ${ }^{102}$

State and federal governments may also conduct or support development within or activities affecting the coastal zone. This is best typified by the current controversy over strategies for achieving national energy goals through outer continental shelf oil and gas production, offshore nuclear development, and deepwater super-tanker ports; these measures necessitate the siting of accompanying onshore facilities. ${ }^{103}$ More traditional state-federal development decisions include water supply systems, ${ }^{104}$ sewer facilities, ${ }^{105}$ and highways. ${ }^{106}$ In addition, the federal government is responsible for major conservation programs within the coastal zone such as national seashores ${ }^{107}$ and wildlife refuges. ${ }^{108}$

In order to explore the complex issue of intergovernmental and interagency cooperation, it is useful to distinguish two broad categories of relationships between these regulatory-developmental programs and coastal zone management: those programs which must be consistent with the coastal management plan and those which need not be. The

99. Id. § 113-229.

100. Id. $\$ \S 104 \mathrm{~B}-3$ to -16 (1972). For a relatively complete listing of state permit and other regulatory programs which may apply within the coastal zone, see id. $\$ 113 \mathrm{~A}$ 125(c) (1975).

101. See The Flood Disaster Protection Act of 1973, 42 U.S.C. $\S \S 4001-127$ (1970), as amended, 42 U.S.C. $\S \S 4001-128$ (Supp. III, 1973).

102. 33 U.S.C. $\$ 403$ (1970); id. \& 1344 (Supp. III, 1973). The U.S. Army Corps of Engineers, which administers this permit program, has recently adopted regulations extending its regulatory jurisdiction to include marshlands and shorelands above mean high tide. 40 Fed. Reg. 31,319, 31,320 (1975).

103. In 1976 , the Department of the Interior plans to lease substantial areas of the outer continental shelf for oil and gas production. Much of the area involved is off the east coast of the United States. See U.S. DEP'T OF THE INTERIor, Draft ENVIronmental Statement: Proposed Increase in Acreage to be Offered for Oll and Gas Leasing on the Outer Continental Shelf (1974). Many coastal states have opposed these plans because of their expected impact on coastal areas. For a review of this controversy, see Whitney, Siting of Energy Facilities in the Coastal Zone-A Critical Regulatory Hiatus, 16 WM. \& MARY L. REv. 805 (1975); Comment, The Rush for Offshore Oil and Gas: Where Things Stand on the Outer Continental Shelf, 5 ENVIRONMENTAL L. REP. 10026 (1975).

104. See 42 U.S.C. $\$ 1962$ et seq. (1970).

105. Federal aid to local governments for wastewater treatınent projects is administered by the Environmental Protection Agency under the authority of 33 U.S.C. $\S \S$ 1281-92 (Supp. III, 1973).

106. The federal-aid highway system is administered by the U.S. Department of Transportation. 23 U.S.C. $\S \S 101-229,304-06$ (1970).

107. The national seashores have been established primarily for recreational use and are managed by the National Park Service of the Department of the Interior. 16 U.S.C. $\S \S 1,459$ (1970).

108. These are administered by the Secretary of the Interior. Id. $\S 668 \mathrm{dd}$. 
first category reflects the fact that many state and federal regulatory programs and even developmental decisions are required to be consistent with or to supplement a state's management program. For example, the CZMA requires that, after approval of a state's management plan, (1) applicants for a federal license or permit obtain certification that the proposed action is consistent with the state's program, ${ }^{109}$ and (2) state and local government apphicants for federal grants show that proposed projects are consistent with the management program. ${ }^{110}$ In addition, water and air quality norms established by federal, state, or local governments are specifically imcorporated and required to be adhered to in the administration of a state's management program. ${ }^{111}$

In this first category, then, the major problem is administrative coordination of the multiple permit requirements of various agencies and levels of government. Considerations of basic fairness, as well as due process, dictate reform of the regulatory process to allow orderly consideration of applications for permits and the elimination of needless duplication. A master permit application form should be devised for coastal development projects subject to multiple agency and governmental regulation. The content of the form could be worked out between local governments, the Coastal Resources Commission, and other state and federal agencies.112 Uniform agency procedures, joint investigation, and public hearings should be provided. A design for the sequence of approval of permit applications should be prepared to allow orderly consideration by each relevant agency and level of government. Points of possible policy conflict and overlapping governmental responsibilities should be identified and resolved through interagency and intergovernmental agreements. Minor projects should be given expedited consideration.

The second category of relationships reflects the fact that some state or federal regulatory-developmental programs may involve a deviation froin the carrying capacity norms of a state's management program.

109. Id. § 1456(c)(3) (Supp. III, 1973).

110. Id. $\$ 1456$ (d). There are two exceptions to this. The requirement is waived if the Secretary of Commerce finds that the project is "consistent with the purposes of" the CZMA or is "necessary in the interest of national security." While either exception, if abused, could prove to be a large hole in the coverage of the Act, it is to be hoped that both will be narrowly construed and seldom applied.

i11. Id. $\$ 1456$ (f).

112. There is precedent for this type of cooperation. For example, the U.S. Army Corps of Engineers and the North Carolina Department of Natural and Economic Resources have promulgated a single form which may be utilized for applications for a permit to do work in navigable waters under 33 U.S.C. $\$ 403$ (1970) and a state dredge and fill permit under N.C. GEN. STAT. \$ 113-229 (Supp. 1975). 
The CZMA requires federal agencies conducting or supporting activities or undertaking development projects to be consistent with a state's management program only "to the maximum extent practicable."113 Furthermore, the Act requires state management programs to provide adequate consideration for "national interest" facilities as well as assurance that land and water uses of regional benefit are not unreasonably restricted. ${ }^{114}$ The North Carolina CAMA does not require other state regulatory and development programs affecting the coastal zone to be consistent with the management program, ${ }^{115}$ though it gives the state authority over the siting of "key facilities," i.e. those having more than local impact, such as energy facilities. ${ }^{116}$

This aspect assures that coastal zone inanagement will be a dynamic process which is open to change and growth. Both coastal planning and the underlying carrying capacity norms will be subject to revision as circumstances change. Such revision may involve either further protection of resources, as in a decision to establish a national seashore, or more intensive use of resources, as in a decision to permit the siting of major energy facilities.

It is important, however, to provide an appropriate process for the consideration and evaluation of such decisions. The best mechanism for this task is the environmental impact statement review process required by the National Environmental Policy Act ${ }^{117}$ (NEPA) and state environmental pohicy acts. ${ }^{118}$ The impact statement, which is required under NEPA in the case of any major federal action having significant impact on the environment, must fully assess probable environmental consequences of alternative courses of action. ${ }^{119}$ Under applicable principles of law, the impact statement would fully disclose not only the direct impact on the environment, but also secondary and cuinulative impacts on growth or population patterns and the effects on

113. 16 U.S.C. $\$ \S 1456$ (c)(1)-(2) (Supp. III, 1973).

114. Id. $\S \S 1455$ (c)(8), (e).

115. See text accompanying notes $43-45$ supra.

116. N.C. GEN. STAT. §\$113A-113(b)(7), -118 (1975).

117. 42 U.S.C. $\$ 4321$ (1970).

118. Most state environmental policy acts are similar to NEPA in requiring an impact statement in the case of a major state action significantly affecting the environment. See, e.g., N.C. GEN. Stat. \$113A-4(2) (1975).

119. 42 U.S.C. $\S 4332(2)(C)$. For a discussion of the case law interpreting "significant impact on the environment" and the issue of when an impact statement is required, see Anderson, The National Environmental Policy Act, in Federal Environmental LAw 238, 325-65 (Environmental Law Institute, E. Dolgin \& T. Guilbert ed. 1974). An impact statement may be necessary not only with regard to federal developmental actions, but also in connection with federal loans, licenses, and permits. Id. 
land use, water, and public services. ${ }^{120}$ The impact statement is required to be prepared before final agency action is taken, and is reviewed by federal agencies concerned with resource management, ${ }^{121}$ such as the Council on Environmental Quality and the Environmental Protection Agency, as well as by state and local agencies and the public. This process provides a basis for informed political decision on proposed adjustınents in the established carrying capacity norms and the concomitant revisions in the coastal management plan.

A related problem is the possibility of conflict between federal and state governments over particular resource use and facility siting questions. This has already occurred with regard to energy-related developmental measures. ${ }^{122}$ It appears that no coastal state has created a mechanisin for dealing with potential federal-state conflicts, ${ }^{123}$ yet these may be too important to be resolved on a case-by-case basis. This defect should be corrected through the establishment of an ongoing coordination process on the state and federal levels. ${ }^{124}$

\section{Taxation Policy and Coastal Zone Management}

In North Carolina, as in most states, the taxation of real and personal property is the dominant source of local government tax revenues. ${ }^{125}$ Local governments exercise this power under a specific delegation of power by the state ${ }^{126}$ and subject to constitutional limitations. ${ }^{127}$ Two major questions arise as a result of the land use restrictions that are characteristic of a coastal area management program. First, what will be the impact of these restrictions on the tax liability of property owners

120. City of Davis v. Coleman, 521 F.2d 661 (9th Cir. 1975); Conservation Council v. Costanzo, 398 F. Supp. 653 (E.D.N.C. 1975); Council on Environmental Quality, Preparation of Environmental Impact Statements: Guidelines, 40 C.F.R. $§ 1500.8$ (a) (3) (ii) (1974)

121. 42 U.S.C. $\S 4332(2)(C)(1970)$.

122. See note 103 supra.

123. Hershman, Achieving Federal-State Coordination in Coastal Resources Management, 16 WM. \& MARY L. ReV. 747, 770 (1975).

124. A proposal for federal-state coordination has been put forward by Professor Hershman. 1d. at 767-71. See also Hershman \& Folkenroth, Coastal Zone Management and Intergovernmental Coordination, 54 ORE. L. Rev. 13 (1975). Perhaps the best attempt at setting up an institution to resolve federal-state conflicts is the national advisory policy board, which has been set up by the Department of the Interior, 40 Fed. Reg. 46, 143 (1975), to obtain state participation in decisions about oil and gas leases on the continental shelf. See Hershman, supra note 123, at 762.

125. In North Carolina during the 1973-74 fiscal year, seventy-six percent of all local revenues were provided by real and personal property taxes. TAX RESEARCH Division. North Carolina Dep't of Revenue, Statistics of Taxation 190 (1974).

126. See N.C. ConsT. art. I, § 8; id. art. V, §§ 2(1)-(5).

127. Id. art. V, \&§ 2(1)-(2). 
within the coastal area? Will property continue to be assessed in the traditional way? If not, what will be the impact on local government? Second, should the property tax mechanism be artificially manipulated to achieve the goals of coastal zone management; for example, should certain lands be preferentially assessed to provide a disincentive for development?

\section{A. Impact on Landowners}

The answer to the first question requires an analysis of the administration of real property appraisal. Under present procedures in North Carolina, for instance, all real property in each local jurisdiction is appraised at least once every eight years. ${ }^{128}$ In addition, property must be reappraised in other years if there has been a value change of more than $\$ 100$ by reason of external factors other than general economic conditions. ${ }^{120}$ A schedule of values and standards is prepared by the county tax supervisor subject to the approval of the county commissioners. ${ }^{130}$ A uniform standard of appraisal must be used, however, requiring real property to be valued at its "true value."131 In determining "true value," the appraisers must take into consideration factors such as location advantages and disadvantages, soil quality, adaptability for various uses, and zoning. ${ }^{132}$ The legal standards for appraisals in North Carolina therefore mandate a determination of the fair market value which takes into account legal restrictions imposed by the police power. An appraisal of property at its highest market value regardless of use restrictions, which is the standard in some states, ${ }^{133}$ would be improper $^{134}$ in the context of coastal management planning.

128. N.C. GEN. STAT. \& 105-286 (1972).

129. Id. $\$ 105-287$ (b)(2) (Supp. 1975).

130. Id. $\S 105-317$.

131. This term is defined as

meaning market value, that is, the price estimated in terms of money at which the property would change hands between a willing and financially able buyer and a willing seller, neither being under any compulsion to buy or to sell and both having reasonable knowledge of all the uses to which the property is adapted and for which it is capable of being used. Id. \& 105-283.

132. Id. \$ 105-317(a)(1).

133. See Heller, The Theory of Property Taxation and Land Use Restrictions, 1974 WIS. L. REv. 751, 780-81.

134. Failure to consider every statutory indicator of value will not vitiate the appraisal, because all the statutory indicia are not applicable to every piece of property. In re Appeal of Broadcasting Corp., 273 N.C. 571, 578, 160 S.E.2d 728, 733 (1968). But the statute contemplates that the property assessors will consider those indicia of value which apply to a given property in appraising its "true value." In re Valuation of Property Located at 411-417 W. Fourth St., 282 N.C. 71, 81, 191 S.E.2d 692, 698 (1972). 
It would thus appear that the designation of areas of environmental concern, and the zoning changes that would be required to implement coastal zone management in North Carolina, will cause major changes in the appraised value of the property within the jurisdiction, simce these police power restrictions would be considered in the appraisal process. Lands subject to the greatest police power restrictions would go down in appraised value, while lands receiving developmental classifications would go up. ${ }^{135}$ The resultant pattern of taxation appears equitable and should be implemented along with the coastal area management program. The taxes foregone on the restricted land would be effectively transferred to lands of increased, or at least undiminished, value in the rest of the community. ${ }^{138}$ It has also been argued that proper zoning and consideration of land use restrictions in property assessment maximizes the tax base of the community because the failure to zone means that the increased value of the unrestricted property would be offset by reductions in the values of all the properties which bear the external costs produced by permitted uses. ${ }^{137}$

Under existing North Carolina law, either the state or owners of restricted coastal land should be able to compel local governments to accept the appraisal readjustments. The state, through the Property Tax Comnission of the Department of Revenue, exercises general and specific supervision over the valuation and taxation of property. ${ }^{138}$ Individual property owners can appeal either the general county valuation standards or specific appraisal decisions to the Commission, ${ }^{130}$ as well as to the courts. ${ }^{140}$

\section{B. Preferential Property Tax Assessment}

Acting on the presumption that the valuation of real property at its lighest rather than its present use encourages the urbanizing conversion of rural land, at least twenty-eight states have enacted preferential

135. That is, the appraised value would increase if the new classification allowed more development than the old one. A separate issue involves the taxation of coastal lands that are subject to public trust restrictions. See text accompanying notes 166-73 infra. Where the claimant to such lands cannot sustain the burden of proving title to such lands, they should be removed froin the tax rolls by local governments. Where lands are privately owned but found to be subject to the public trust doctrine, this fact should be taken into account in determining "true value."

136. Heller, supra note 133 , at 784.

137. Id. at 783 .

138. N.C. GEN. STAT. $§ \S 105-288$ to -291 (Supp. 1975).

139. Id. § 105-324.

140. In re Valuation of Property Located at 411-417 W. Fourth St., 282 N.C. 71, 191 S.E.2d 692 (1972); In re King, 281 N.C. 533, 189 S.E.2d 158 (1972). 
assessment statutes for farmland. ${ }^{141}$ The preferential assessment idea is based on several premises. First, it was intended to provide tax relief for farmers whose lands had appreciated in value due to developmental pressures, thus seeking to maintain the agricultural use of productive land and to insulate farmers from the financial impact of escalating tax bills. ${ }^{142}$ Second, aside from its justification as a direct farm subsidy, preferential tax pohicy was suggested as a means of preserving a dwindling supply of prime arable land. Since flat farmland could be easily converted into mass housing developments, it was feared that agricultural productivity near large inarkets would be destroyed without some preventive measure. ${ }^{143}$ Third, in the early 1960 s, conservatiomsts considered the preferential tax assessment prograins an important techmique for the provision of open space; similar justifications were presented for preferential tax plans directed towards the protection of forest and open space lands. ${ }^{144}$ Finally, most if not all state preferential assessment programs have required that lost or uncollected taxes be recaptured upon the sale or change of use of protected lands. In some instances additional penalties are also imcurred. The tax recapture and the penalties are intended as inducements to maintain current land use patterns and as deterrents against speculation and rapid development. ${ }^{145}$

Not surprisingly, preferential taxation policy has received substantial criticism and has stirred considerable debate. Several arguments are raised against it. First, the techmique has been described as a tax windfall for large corporate agricultural enterprises and speculators. Since the preferential assessinent is uniformly apphicable to all landowners using their property for agricultural purposes, the large agri-business firm gains along with the economically hard-pressed small farmer. ${ }^{140}$ In addition, the prograin applies on a statewide basis so that land well beyond the pressures of urban developinent receives the same preferen-

141. Henke, Preferential Property Tax Treatment for Farmland, 53 ORE. L. REv. 117, $117 \mathrm{n.1}$ (1974). North Carolina is included in this group, although its preferential system applies not only to agricultural lands, but also to realty used in forestry and horticultural activities. N.C. GeN. STAT. \$§ 105-277.2, -277.3 (Supp. 1975).

142. See Henke, supra note 141, at 119 n.8; Note, Ad Valorem Taxation of Agricultural Land in Tennessee, 4 MeMphis St. L. Rev. 127, 136 n.38 (1973) (Tennessee farm property taxes increased by 241 percent between 1960 and 1971).

143. Note, Ad Valorem Taxation, supra note 142, at 135.

144. Henke, supra note 141 , at 120.

145. Deferred taxation is intended to be an incentive to landowners to encourage them to maintain the existing land use. Recapture and penalty provisions serve as financial sanctions against land use conversions. Economic self interest of landowners is thus the prime factor in the success of the system.

146. However, this does not appear to be the case in North Carolina, where preferential tax benefits are available only for individually owned land. See note 154 infra. 
tial treatment as does realty directly bordering urban areas. Early analysis of California's Williamson Act $^{\mathbf{1 4 7}}$ found that most preferentially assessed land was "below average value nonprime agricultural land located some distance from incorporated areas."148 Consequently, by its over-inclusiveness the Act protected property in only slight danger of immediate conversion to nonfarni use.

Second, the metliod has been criticized for failing to discourage "premature and unnecessary conversion of agricultural land to nonagricultural use."148 Research studies have borne this out. In Montgomery County, Maryland, preferential assessinent has been found (1) to prolong the pre-development or speculative period when the land is not agriculturally productive and (2) to cause a slight delay in conversion of no more than one to one and a half years. ${ }^{150}$ Therefore, the effect of preferential assessment on regional development appears to be minor.

Third, preferential assessment also causes a reduction in the tax base of the taxing jurisdiction and hence reduces local government revenues in these areas. This phenomenon results in a severe fiscal impact on tax districts which are far removed from developmental pressures, and in fact transfers the tax burden to the nonpreferred land uses in those places. ${ }^{151}$ The United States Department of Agriculture has estimated that the revenue loss necessitated by lowered property assessments in Montgonery County, Maryland, could liave supported a vigorous public land acquisition program..$^{152}$ According to the study, one percent of the preferentially assessed agricultural land-amounting to more than 1500 acres-could have been purchased in fee with the revenues lost during each of the years the program was in effect. If the figures are accurate, a direct public effort to acquire ownerslip of open land would have been considerably more effective in slowing development and preserving open space. Moreover, the predicted negative impact of the tax rollback or recapture provisions may in fact be illusory in the case of the land speculator. Since property taxes are deductible expenses used to offset ordinary income, and in soine cases capital gains,

147. CaL. Gov'T CodE $\$ \S 51230-95$ (West Supp. 1975).

148. Carman \& Polson, Tax Shifts Occurring as a Result of Differential Assessment of Farmland: California, 1968-69, 24 NAT'L TAX J. 449, 455 (1971).

149. Id.; see Henke, supra note 141, at 123.

150. Washington Center for Metropolitan Studies, Taxation and Development, The Use of Tax Policies for Preserving Open Space and Improving DevelOPMENT PATTERNS IN THE Bi-COUNTY REgion 19 (1968).

151. Carman \& Polson, supra note 148, at 456; Henke, supra note 141, at 125.

152. Henke, supra note 141 , at 126 n.39. 
their postponement and imposition at the time of the land's sale may be beneficial to the seller in terms of federal income tax. ${ }^{153}$

This combination of criticisms presents a solid challenge to the idea that preferential assessment by itself can accomplish its stated purposes. ${ }^{154}$

153. Real property taxes are deductible for the taxable year in which they are "paid or accrued." INT. REv. CODE of 1954, \& 164(a)(1). Since the deferred taxes would be paid in the year of conversion to a more intensive use, the deduction would be applicable against the large capital gains or income received in that year.

154. With this background, the North Carolina preferential assessment mechanism can be examined to determine if it can be modified to achieve the planning goals of the Coastal Area Management Act. The 1973 General Assembly enacted legislation, N.C. GeN. STAT. $\S \S 105-277.2$ to -277.7 (Supp. 1975), dealing with the preferential assessment of agricultural, forest, and horticultural lands within the state. Under the statute, these three classes of property are defined in terms of land use, acreage, and form of ownership. The qualifying property owner must file an application with the county tax supervisor to have his land aud nonstructural improvements appraised at present use value. Id. $\S 105-277.4(\mathrm{a})$. From that point on, dual records are maintained on the qualified property, one set showing true or fair market value and the other reflecting the property's value in its present use. Annual property tax is paid on the basis of present use value. The difference between this and the tax which would have been paid without the preferential assessment is carried forward as a deferred tax and represents a recorded lien on the real property. The tax deferral may continue indefinitely, so long as the land use remains unchanged and the property title is retained by the original landowner or his immediate family. Upon disqualification, all deferred taxes for the preceding five years become payable immediately, along with statutory interest charges accruing as of the date that the taxes originally became due. Id. $\$ 105-277.4(\mathrm{c})$. For a computation of the interest, see id. $\$ \S 105-360(a)(2)-(3)$ (1972). In addition, if the property owner fails to notify the county tax supervisor of the disqualification, a ten percent penalty is levied on the deferred tax and the interest. Id. \$ 105-277.5 (Supp. 1975). In simpler terms, the General Assembly has acted to reduce the property tax burden on the landowning farmer and forester in North Carolina. In order to satisfy the constitutional "uniformity" requirement contained in N.C. CoNsT. art. V, § 2(1), preferentially treated land was classified by its use characteristics. In this way all privately owned agricultural land in the state could be taxed under the same scheme. Since farm and forestry lands are not concentrated in any one region of the state, the statutory change did not unduly benefit any one area and did not become unlawful local or special legislation. In addition, the legislature carefully limited the application of the preferential program so as to aid the small family farm and not the agri-business enterprise. Only "individually owned land" is specially treated by the statute, N.C. GEN. STAT. \$ $105-$ 277.3(a) (Supp. 1975), and corporate holdings are excluded unless the corporation's principal business is agriculture, forestry, or horticulture and all its shareholders are natural persons, or the spouse, siblings, or parents of such persons, who are actively engaged in agriculture, forestry, or horticulture. Id. $\$ 105-277.2(4)$. This attempt to restrict the benefits of the act may be futile since land title can be easily transferred, and furthermore, many land speculators will not seek use-value appraisals. Finally, the statute emulates most earlier preferential assessment legislation by enacting strict recapture provisions. Change of use and transfer outside of an immediate family circle constitute independent grounds for disqualification and tax penalty. Id. $\S 105-277.5(\mathrm{c})$.

Since the statute became effective on January 1, 1974, there is only one tax year of experience with the scheme, so it is difficult to assess its impact. Froin the experi- 


\section{GOVERnMental ACQUisition AND OWNERShIP Policies and COASTAL Zone MaNagement}

\section{A. Coordinated Use of the Acquisition and Ownership Powers to Implement Coastal Zone Management}

Public acquisition and ownership of land is certainly the most direct method for controlling its use. Yet the use of this governmental power is not emphasized under federal and state coastal zone management laws. Under the federal CZMA, the only mention of acquisition as an implementation tool is the authorization of federal grants of up to fifty percent of the costs of acquisition, development, and operation by a coastal state of estuarine sanctuaries created for the purpose of studymg the natural and human processes occurring within estuarine areas. ${ }^{165}$ The North Carolina CAMA deals with acquisition as a policy tool only by providing for the use of the condemnation power to acquire a fee or lesser interest in order to protect an area of environmental concern where it has been judicially determined that a regulatory order affecting the area constitutes a "taking."156

Other statutory provisions and legal doctrines, however, provide a broader basis for using the acquisition and ownership power as a coastal management implementation device. In North Carolina, local governments may acquire land by purchase, gift, or otherwise, not only for

ence of other states, however, it would seem that North Carolina's preferential assessment statute will not be particularly helpful in the implementation of the coastal zone management program. Furthermore, it does not seem to be necessary. Present law, as stated above, see notes $128-40$ and accompanying text, can permit the redistribution of tax costs on the basis of the designation of areas of environmental concern and the zoning process. Further preferential assessment of three categories of land appears to skew taxation policy unjustifiably.

It could be argued that the present statutory formulation should be permitted to operate unaltered in the hope that it wonld accomplish its objective of preserving open space in the CAMA areas of environmental concern and in other ecologically important lands. This argument, however, is based on several assumptions of questionable validity. First, it requires the environmentally critical land to be currently used for agriculture, forestry, or horticultnre in order to qualify for preferential assessment; lands of equal environmental value, but now used for other purposes, are excluded. Second, the property owners are assumed to be individuals who wonld find it financially advantageous to seek a reappraisal and reassessment based on the property's use value. Third, preferential assessment and its tax deferral provisions are assumed to be effective in preventing changes in the use of the land even after the possible monetary return becomes substantial and development permits are available. Any correlation between the intended effects of the preferential assessment program and the implementation of local CAMA land use planning would be little more than coincidental and hardly the result of rational policy choice.

155. 16 U.S.C. $\$ 1461$ (Supp. III, 1973).

156. N.C. Gen. Stat. § 113A-123 (1975). 
parks and recreational purposes, ${ }^{107}$, but also for conservation or historic purposes or to preserve an area of great natural scenic beauty. ${ }^{158}$ In the latter case cities and counties are expressly authorized to acquire or accept less than fee interests in real property; ${ }^{159}$ this makes possible a program for acquisition of development rights and of scenic and conservation easements through which the fee interest remains in private hands. ${ }^{100}$

Under existing law the state has analogous authority. The Department of Natural and Economic Resources has broad powers to acquire lands for state forests and parks, ${ }^{101}$ and the Wildlife Resources Commission may purchase or accept property to establish wildlife refuges and management areas. ${ }^{162}$ In addition, a public body, the North Carolina Land Conservancy Corporation, has been created to acquire and preserve areas in their natural state. ${ }^{103}$ This entity is authorized to acquire fee simple or less than fee simple interests in land $\mathrm{d}^{104}$ and could thus institute a state conservation easenient or development rights program. Similar structures are available in several other coastal states. ${ }^{106}$

A common law concept of state ownership, the public trust doctrine, ${ }^{100}$ is also important in coastal areas. In North Carolina, the public trust doctrine would appear to affirm state title to all tidelands below mean high tide ${ }^{107}$ except where private claimants can show, with respect to specific parcels, a "connected chain of title from the sovereign to (them) for the identical lands claimed by (them)."108 Private claims to submerged land can therefore be settled only on a case-by-case

157. Id. § 160A-353 (Supp. 1975).

158. Id. $\$ \S 160 \mathrm{~A}-403,-407$ (1972).

159. Id. $\$ 160 \mathrm{~A}-403$.

160. See Campbell, Conservation Easements: An Effective Tool in the Environmentalist's Kit, 39 Pop. Gov't 36 (Apr. 1973).

161. N.C. GeN. STAT. §§ 113-34, -40 (1975).

162. Id. § 113-306.

163. Id. $\$ \S 113 \mathrm{~A}-135$ to -143 .

164. Id. § 113A-139(12).

165. E.g., Conn. Gen. Stat. ANn. § 22a-25 (1975); Fla. Stat. ANn. § 259.04 (1975); TeX. Rev. Civ. Stat. art. 5415e-1, § 6(f) (Supp. 1974).

166. This doctrine holds that title to coastal and other submerged lands is vested in the state in trust for the people so that they may navigate, fish, and carry on commerce in the waters involved. The precise limits of the public trust in North Carolina are uncertain. For discussion of the problems, see Rice, Estuarine Land of North Carolina: Legal Aspects of Ownership, Use and Control, 46 N.C.L. REv. 779 (1968); Schoenbaum, supra note 38; Comment, Defining Navigable Waters and the Application of the PublicTrust Doctrine in North Carolina: A History and Analysis, 49 N.C.L. REv. 888 (1971).

167. See Schoenbaum, supra note 38, at 15.

168. State v. Brooks, 279 N.C. 45, 50, 181 S.E.2d 553, 556 (1971), quoting Sledge v. Miller, 249 N.C. 447,451 , 106 S.E.2d 868, 872 (1959). 
basis, ${ }^{169}$ and North Carolina has only begun the task of determining their validity. ${ }^{170}$ As a practical matter, however, it may be unimportant whether title to certain parcels of submerged lands is held by private parties; since the title origmally: held by the state was burdened with a public trust, the grantee of the state could not obtain a better title than his grantor. ${ }^{171}$ It would appear, therefore, that private parties would also hold such lands subject to the trust, and observance of the trust would generally require that such lands be maintained in their natural state. $^{172}$ Government regulation of these lands in order to preserve the trust would not appear to present any "taking" problem. ${ }^{173}$

These ownership and acquisition powers of state and local governnients have great potential for use as a policy instrument im coastal zone management. They should be systematically employed to iniplenient planning and to protect areas of environmental concern where regulation is impractical or unconstitutional. In order to be fully effective, however, they must be used in ways that are consistent, or at least coordinated, with the coastal management plan. ${ }^{174}$

\section{B. Additional Possible Uses of the Acquisition Power}

1. Transferable Development Rights. Transferable Development Rights (TDR) systems have rising importance in the land use planning field. ${ }^{175}$ Originally developed and used as a means of preserving central

169. Even if a connected chain of title can be proved, the grant by the state may be voidable if it is so broad that it significantly impairs public rights. Illinois Cent. R.R. v. Illinois, 146 U.S. 387, 452-53 (1892).

170. In 1965 , North Carolina began an attempt to solve this problem by requiring that claimants of coastal submerged lands register such claims on or before January 1 , 1970. N.C. GEN. STAT. \& 113-205 (1975). These claims have now been mapped, but no systematic atteinpt has been made to determine their validity. Telephone Interview with William Rainey, Assistant Attorney General, State of North Carolina, Sept. 5, 1975.

171. See Schoenbaum, supra note 38 , at 17-18.

172. See Township of Grosse Ile v. Dunbar \& Sullivan Dredging Co., 15 Mich. App. 556, 167 N.W.2d 311 (1969).

173. That is, the "taking" doctrine would not seem to apply to use restrictions designed to enforce the public trust because the private owner could not assert the taking of any proprietary interest.

174. The North Carolina CAMA, however, contains no provision requiring consistency and coordination between governmental acquisition powers and planning.

175. See generally Carmichael, Transferable Development Rights as a Basis for Land Use Control, 2 FLA. St. L. REv. 35 (1974); Costonis, Development Rights Transfer: An Exploratory Essay, 83 YALE L.J. 75 (1973); Marcus, Mandatory Development Rights Transfer and the Taking Clause: The Case of Manhattan's Tudor City Parks, 24 BuFFALO L. REV, 77 (1974); Note, The Unconstitutionality of Transferable Development Rights, 84 YALE L.J. 1101, 1101-02 (1975). 
city landmarks, TDR is now being experimented with as a tool to preserve existing open spaces and environmentally sensitive areas through the transfer of development rights to other areas from the land sought to be preserved. Pilot programs and variations of TDR are being considered or used by local governments in several states. ${ }^{178}$

The prototype of the use of the TDR for ecological preservation is the plan developed by Professor John J. Costonis for Puerto Rico. ${ }^{177}$ This involves the designation of environmentally sensitive areas as well as the earmarking of lands where greater development would be desirable. Criteria would be estabhshed for environmentally sensitive areas so that any development which would damage the protected resources would be prohibited. Owners of other lands would be subject to two sets of zoming restrictions: they would be free to develop their lands up to the limits provided in the first set of restrictions, but they would have to purchase development rights from a government planning board if they wanted to develop further, up to the limits provided in the second set. The fund thus established would be used to compensate owners of environmentally sensitive lands who are denied a reasonable return because of applicable restrictions. ${ }^{178}$ As thus conceived, TDR becomes an innovative method to supplement regulatory restrictions by providing compensation for lost land values.

It is evident that before this or any other variation of a TDR systen can be used as a technique to implenient coastal zone inanagement, many legal and policy questions must be resolved. It is uncertain whether such a concept could withstand constitutional attack. ${ }^{179}$ Furthermore, TDR systems have never been attempted in a relatively large geographical area, such as the North Carolina coastal zone. Nevertheless, a TDR program may have value in coastal zone nuanagement, and appropriate enabling legislation should be passed in order to encourage local jurisdictions to experiment with this device.

2. Land Banking. Land banking is another use of the government acquisition power that has been proposed as a way of promoting more efficient land development patterns and conserving natural re-

176. See Rose, The Transfer of Development Rights: A Preview of an Evolving Concept, 3 ReAL Estate L.J. 330, 337-52 (1975).

177. Costonis, supra note 175 , at $92-95$.

178. For a summary of TDR in general, see Note, supra note 175, at 1101-02.

179. Some of the constitutional questions include whether the restrictions on development violate substantive due process and equal protection concepts as well as whether the TDR payments will be considered just compensation. For differing views of the resolution of these issues, compare Costonis, supra note 175, at 107-21, with Note, supra note 175 . 
sources. ${ }^{180}$ Although it has been successfully used elsewhere, ${ }^{181}$ land banking is an untried nechanism in the United States. The technique involves the purchase of land by government in amounts sufficiently large that land use patterns are affected, the holding of land without immediately committing it to a specific future use, and the gradual disposition of the land to government and private parties.

The use of this technique has been encouraged by recent developnients. The federal Community Development Act of 1974 allows the use of federal funds by local governments for the purchase of land for "the guidance of urban development."182 Moreover, the influential American Law Institute (ALI) has adopted an article for the initiation of a state system of land banking as a part of its Model Land Development Code. ${ }^{183}$ The ALI proposal would rely on a state land reserve agency which would be empowered to acquire, hold, and dispose of lands according to the policies and limitations of the state land development plan. ${ }^{184}$ Local governments would participate in the banking system through agreements with the banking agency that designate the latter as the local government's agent for the purpose of acquiring, managing, and disposing of lands. ${ }^{185}$

Here too, however, many legal, economic, and social policy questions must be resolved before land banking can be relied upon as an instrument for coastal zone management. It is doubtful whether private property can be acquired or condemned for some unspecified future use. ${ }^{186}$ Furthermore, the techmique would have a substantial impact on property tax revenues of local governments. ${ }^{187}$ Land banking would thus appear to be a useful policy instrument only in the long term, if at all.

3. Natural Area Preservation Through a Land Conservancy Trust. In contrast to transferable development rights and land banking propos-

180. See generally Fishman, Public Land Banking: Examination of a Management Technique, in 3 MANAGEMENT AND CoNTROL OF GRowth 61 (R. Scott ed. 1975).

181. Passow, Land Reserves and Teamwork in Planning Stockholm, $36 \mathrm{~J}$. AM. INST. PlanNers 179 (1970).

182. 42 U.S.C.A. $\$ 5305($ a) (1) (Supp. 1976).

183. AlI-ABA Model Land Development Code art. 6 (Proposed Official Draft, 1975).

184. Id. $\S \S 6-102,-201,-202$.

185. Id. $\$ 6-201$.

186. This question has been resolved in the context of land banking in only one jurisdiction; in Commonwealth v. Rosso, 95 P.R.R. 488 (1967), appeal dismissed, 393 U.S. 14 (1968), the Supreme Court of Puerto Rico upheld land banking legislation.

187. The ALI proposal would exempt "banked" land from local property taxes. ALIABA Model Land Development Code art. 6-203 (Proposed Official Draft, 1975). 
als, which cannot be expected to play an immediate part in coastal zone management, the Nature Conservancy Trust device is a potentially important tool for preservation and the implementation of planning. In North Carolina, the Land Conservancy Corporation is authorized to purchase and accept donations of fee and lesser interests in land and to hold them in their natural state. ${ }^{188}$ It is operated by a nine member board of trustees. ${ }^{180}$ This public body could be effectively used in coastal zone management to implement a planned program for the acquisition of natural areas, including developinent rights and conservation easements, in the coastal area. The pattern of acquisition could be designed to ensure the survival of the biotic diversity and natural systems of the region. The Land Conservancy Corporation also has flexible powers for rapid acquisition of areas of environmental concern that have been so designated by the Coastal Resources Commission and are threatened with development. ${ }^{190}$ It is also empowered to enter into agreements with local governments and state agencies ${ }^{101}$ and could thus act as an agent for local governments and state agencies in land acquisition where ultimate disposition is to be made to them. ${ }^{192}$ The Corporation can also accept donations and bequests of lands and money, ${ }^{103}$ and should promulgate information on the substantial tax advantages under existing law which accrue to such gifts and bequests. ${ }^{194}$

188. N.C. GEN. STAT. $\$ \S 113 A-135,-139$ (1975).

189. Id. \& 113A-137.

190. Id. \& 113A-136.

191. Id. \& 113A-139(7).

192. See, e.g., Durham Morning Herald, Aug. 8, 1973, at A1, col. 1 (North Carolina accepted deed of land from Nature Conservancy for Eno River Park).

193. N.C. GEN. STAT. $\$ \S 113 A-139(6)$, (8) (1975).

194. For a thorough examination of these tax advantages, see Thomas, Transfers of Land to the State for Conservation Purposes: Methods, Guarantees, and Tax Analysis for Prospective Donors, 36 Ono ST. L.J. 545 (1975). See also Campbell, supra note 160 (analysis of property tax advantages under North Carolina law).

It is evident that the statutory provisions governing the Land Conservancy Corporation should be reformed, however, if it is to realize its full potential. First, the board of trustees is required to contain two members each from the State House of Representatives and the State Senate. N.C. GEN. STAT. \& 113A-137 (1975). This requirement politicizes the board of trustees, and should be elininated. Second, the flexibility of the Corporation is limited by the fact that it may not use appropriated state funds to purchase property without approval of the Department of Administration, the Governor, and the Council of State. Id. \$ 113A-142. (The North Carolina Council of State is, in effect, the state Cabinet.) No land can be acquired without approval by the Council of State. Id. $\S 113 \mathrm{~A}-143$. These severe restrictions seem unnecessary, especially in view of the fact that the Corporation has no power of condennation. Third, the Corporation should be given the specific authority to borrow money and to issue bonds to finance land acquisition. This power is absent under current law. 


\section{CONCLUSION}

States that are in the process of instituting regional land use planning for the purpose of protecting valuable resources and critical environmental areas will soon face the problem of how to implement their plans. They will find that the traditional legal tools for implemnentation of planning are inadequate for the task. Newer land use guidance techmiques, such as growth-control systems, land banking, and transferable development rights, while valuable, have not been sufficiently developed or tested to serve as realistic alternatives for the implementation of planning in a geographically large region. This Article has presented a third alternative, the coordinated use of traditional mechanisms to influence land use through government regulation, taxing, and acquisition. This land use guidance mechanism can be instituted largely without additional legislation; to realize the full potential of this inethod, however, legal reforms are needed, especially on the local level. The keys to the success of such an approach are intergovernmental cooperation by federal, state, and local decision-makers, and the awareness of their respective powers and the functions of these powers within the land use guidance system. 